\title{
RNA-Binding Protein Nova-2
}

National Cancer Institute

\section{Source}

National Cancer Institute. RNA-Binding Protein Nova-2. NCI Thesaurus. Code C33977.

RNA-binding protein Nova-2 (492 aa, $49 \mathrm{kDa}$ ) is encoded by the human NOVA2 gene.

This protein plays a role in binding to single stranded RNA. 